\title{
The misplaced management of bees
}

\author{
Benoit Geslin ${ }^{1}$, Lise Ropars ${ }^{2}$, Marie Zakardjian ${ }^{1}$, and Floriane Flacher ${ }^{1}$ \\ ${ }^{1}$ Aix Marseille Université, Université Avignon \\ ${ }^{2}$ Franche-Comte University
}

January 26, 2022

\begin{abstract}
Problem statement: To halt global biodiversity decline, many conservation measures are set up by citizens, companies, or stakeholders. However, even if originally well-intentioned, some of these actions could have direct or indirect negative effects on biodiversity when ecology is not accounted for. The management of bees is a good example of such misplaced conservation practices. We identified three successive errors in the management of bees which can disrupt the focus on real conservation issues: the multiplication of honey bee hives, the installation of insect hotels, the trade of solitary bee cocoons for release into the wild. To help the bees, as well as biodiversity in general, we must consider prioritizing efficient conservation measures which consider more broadly the complexity of ecosystems.
\end{abstract}

\section{Title: The misplaced management of bees}

Authors: Benoît Geslin ${ }^{1}$, Lise Ropars $^{1,2}$, Marie Zakardjian ${ }^{1} \&$ Floriane Flacher ${ }^{1}$

${ }^{1}$ IMBE, Aix Marseille University, Avignon Univ., CNRS, IRD, Marseille, France.

2 ThéMA, UMR 6049 CNRS/Université de Bourgogne Franche-Comté, Besançon, France.

ORCID Numbers - B. Geslin: 0000-0002-2464-7998; F. Flacher: 0000-0002-7871-4690; L. Ropars: 0000-0001$7621-2825$

Corresponding author: Geslin, B. (benoit.geslin@imbe.fr) - Twitter: @bengeslin - laboratory website:https://www.imbe.fr/

Author contributions: B.G. conceived the idea and wrote a first draft. BG, FF \& LR gathered the data. All authors contributed to the writing of the manuscript, the editing, and the manuscript formatting.

Data statement: Should the manuscript be accepted for publication, the data will be available in an approved public repository, and a DOI will be provided

Number of words in the main text excluding titles: 2096

Number of words in the abstract: 119

Number of figures: 1

Number of tables: 0

Number of references: 49

Abstract : To halt global biodiversity decline, many conservation measures are set up by citizens, companies, or stakeholders. However, even if originally well-intentioned, some of these actions could have direct or indirect negative effects on biodiversity when ecology is not accounted for. The management of bees is a good example of such misplaced conservation practices. We identified three successive errors in the management of bees 
which can disrupt the focus on real conservation issues: the multiplication of honeybee hives, the installation of insect hotels, the trade of solitary bee cocoons for release into the wild. To help the bees, as well as biodiversity in general, we must consider prioritizing efficient conservation measures which consider more broadly the complexity of ecosystems.

\section{Viewpoint :}

In a recent perspective paper, Ford et al. (2021) developed the convincing concept of "misplaced conservation" which include actions that, due to misinformation, directly or indirectly "harm biodiversity, waste resources, misinform the public, and (or) delegitimize evidence". Misplaced conservation practices are thus often driven by people who want to help biodiversity but end up unwillingly harming it. The example of bee management is a good illustration of repeated misplaced conservation both regarding wild and domestic bees.

Bees suffer from anthropogenic pressures at a global scale with reported declines of their populations and species (Zattara \& Aizen 2021). Due to their value as pollinators for wild plants and crops, bees are also perceived as a flagship of biodiversity by the general public (Sumneret al. 2018). This positive image, widely encouraged by mass media (Smith \& Saunders 2016), has increased the willingness to save the bees in the population, and practices aimed at helping them have multiplied among environmentally friendly citizens (Fig. 1 - Stangeet al. 2017; Egerer \& Kowarik 2020). Here, we explored three examples of misplaced management of bees and discussed consequences for their conservation and for biodiversity.

\section{Adding honeybee hives increases pressures on native bees}

An iconic practice originally designed at helping bees is the introduction of beehives. In the past few years, citizens, companies, or collectivities have started to welcome beehives in their facilities and their number has consequently sharply increased particularly in cities such as in London, Paris and Berlin (Lorenz \& Stark 2015; Stevensonet al. 2020) and in natural areas (Herrera 2020). For example, the number of beehives in Paris has been estimated from 600 in 2015 in Paris to more than 2600 in 2019 (French ministry of Agriculture). But Apis mellifera, the honey-producing domestic bee is not the sole bee; to date, 20000 bee species have been described worldwide, most of them being solitary and nesting in the ground (Michener 2007). Historically, Apis mellifera has been transported from Europe across the world for honey production and has been many times associated with the decline of local populations of bees (Thomson 2004; Valido et al. 2019). Therefore, artificially supporting Apis mellifera, which is not threatened of extinction, does not help the hundreds of wild solitary bee species (Colla \& MacIvor 2017; Geldmann \& González-Varo 2018; Baldock 2020). Instead, increasing the density of honeybees could affect wild bees through competition for floral ressource, pathogens spillover or disruption of pollination networks (Geslin et al. 2017; Mallinger et al. 2017). Over the past few years, the body of literature highlighting negative effects of honeybees on wild pollinators has sharply grown (Herbertsson et al. 2016; Magrachet al. 2017; Henry \& Rodet 2018; Valido et al. 2019; Hunget al. 2019; Ropars et al. 2019, 2022; Angelella et al. 2021; Renner et al. 2021). For example, as evidenced in Paris, the increase in the number of hives has resulted in exploitative competition for floral resources exerted by honeybees on wild pollinators (Ropars et al. 2019) and same trends have been found in natural reserves or flowering rich habitats in France, Spain and the United States (Torné-Noguera et al. 2016; Henry \& Rodet 2018; Hung et al. 2019; Ropars et al. 2020). Therefore, following the framework of Ford et al. (2021), focusing policies and conservation initiative on the sole honeybee is the first example of misplaced conservation of bees through a) the misinformation of public on the decline of honeybees and their importance in the maintenance of ecosystems, b) the waste in funding and resources potentially allocated to wild pollinators, c) the direct harm on biodiversity through competition (Colla \& MacIvor 2017; Geldmann \& González-Varo 2018; Egerer \& Kowarik 2020).

\section{Bee hotels: a springboard for the invasion of exotic bees}

In the meantime, scientific knowledge has also progressed regarding the status of wild solitary bees. National research campaigns and conservation plans have been launched in many countries such as in the United States, England, France and Germany (Drossart \& Gérard 2020; Schatz et al. 2021). Citizens' science programs have also been developed, inviting many civilians to contribute to awareness on solitary bees (Deguines et al. 
2018; Koffler et al. 2021). To a certain extent, the increase information on the importance of wild bees and the growing number of evidence on competitive interactions exerted by honeybees on wild bees, may have opened new avenues for other managing practices in favor of wild bees such as the establishment of bees hotels (MacIvor \& Packer 2015; von Königslöw et al. 2019). Historically, bee hotels were mainly used as trap nests to sample wild bees or as a tool to improve pollination service to crops (Daineseet al. 2018). Now, the purpose behind this practice is to provide aboveground nesting bees (mostly Xylocopinae and Megachilidae) with nesting substrates that can be locally limiting and therefore help to support their populations. The use of trap nests as bee hotels has also become widely popular (MacIvor \& Packer 2015) and they are nowadays commonly sold in garden centres and on online platforms with, for example, more than 1,000 offers listed on Amazon at a price up to 300 US\$ (von Königslöw et al. 2019).

However, the multiplication of bee hotels could also be an ecologically unsound practice because they can shelter invasive alien bee species, thereby potentially facilitating their spread (MacIvor \& Packer 2015; Geslin et al. 2020; Straffon-Díaz et al. 2021). This second misplaced management is highly problematic, as invasive alien insects can have severe consequences for ecosystems and the economy (Bradshaw et al. 2016). A convincing example involving bees is the case of Bombus terrestris, which has become invasive worldwide (Aizen et al. 2020). The commercial introduction of $B$. terrestris nest boxes for pollination services in greenhouses has had dramatic consequences for native wild bumblebee populations in Japan, South America, New Zealand and Australia (Geslin et al.2017). Introduced exotic bumblebees have escaped and robbed flowering resources, thereby disrupting the native bumblebee populations and the structure of plant-pollinator networks (Geslin et al. 2017). More worryingly, exotic bumblebees have brought several pathogens and parasites that have infected native bees (Graystock et al. 2013). Hence, in Argentina, the rapid local extinction of the endemic bumblebee $B$. dalhbomii has been associated with the spread of $B$. terrestris, most likely due to pathogen spillover (Aizen et al.2020).

To date, 80 bee species have been recorded outside of their native range and even though not all are invasive their impact on native ecosystems may be important (Russo et al. 2021). For example, Megachile sculpturalis , a bee native to Asia and accidentally introduced in North America and Europe, has been shown to exhibit aggressive behaviour toward the local bee fauna through nest eviction and competition (Geslin et al. 2020). This species commonly nests in bee hotels whose can, in turn, favour its spread (MacIvor \& Packer 2015; Le Féon et al. 2018; Geslin et al. 2020). Recently, Straffon-Díaz et al. (2021) showed that M. sculpturaliscolonized the tunnels of native Osmia spp. in insect hotels while blocking the entrance of their nests. They also showed that M. sculpturalis ' brood could be infested by local parasites without reducing drastically its reproductive success potentially suggesting apparent competition with native bees through increase in the abundance of parasites for native species. Finally, because most of wild solitary bees ( $70-75 \%$; Michener 2007) nest in the ground, bee hotels are susceptible to host less than $15 \%$ of all bee species (Rahimiet al. 2021). Overall, we argue that the installation of bee hotels is a misplaced conservation practice because of a) the misinformation of public: evidence showing the capacity of bee hotels to support cavity nesting bee populations is weak (Rahimi et al.2021); b) the misallocation of resources: instead of adding artificial nests, we suggest to conserve natural habitat susceptible to shelter native population of bees, including belowground nesting bees and c) potential indirect impacts on biodiversity: bee hotels could promote the spread of invasive species with repercussions on native flora and fauna (Ivanov \& Fateryga 2019; Geslin et al. 2020).

\section{Increasing trade in wild bee cocoons could disrupt pollinator communities}

Recently, a third misplaced conservation practice has emerged: people thought of filling up themselves bee hotels with cocoons to control both the species and the occupancy rate. To do so, online companies selling wild bee cocoons for bee hotels have arisen (Fig. 1). Before this new trend, few bee species was reared and commercialized for trap nests mostly to pollinate crops (Aizen et al. 2020) and the commercialization of wild bees was restricted to professional agricultural practices. However, these companies now routinely sell cocoons of Osmia species (mason bees) and Megachile(leafcutter bees) to anyone wanting to purchase wild bees (e.g., https://crownbees.com/; https://masonbeesforsale.com/, among others). Overall, the potential invasiveness of insects has been associated to their global commercial success (Gippet \& Bertelsmeier 2021) 
and trade volumes (Bang \& Courchamp 2021). Therefore, in October 2021, using the keywords "buy bee cocoons", "buy wild bees" and "wild bees for sale" we searched in Google in seven languages (English, French, German, Italian, Russian, Spanish, and Chinese) all website selling wild bee cocoons online. We found 42 websites selling cocoons for a total of eight different species (Supplementary material S1). While some sellers appeared to restrict their shipping to native species or those from a few neighbouring countries, it was very easy to buy cocoons from another continent online. For example, in June 2021, a package shipped from France to Seattle (USA), was seized by the biosecurity service of New Caledonia, a French tropical archipelago. Inside the package, bamboo twigs containing 23 lived cocoons of wild bees (Osmia sp. ) with two recently emerged females (H. Jourdan, pers. obs .).

By promoting the trade of wild bees, we believe that companies selling bee cocoons create a window of opportunities for ecological disturbances inside and outside of their native area (Fig. 1). The unregulated trade of insects worldwide has already caused considerable damages not only to ecosystems but also to the economy (Diagne et al. 2021) and is predicted to become increasingly problematic (Bang \& Courchamp 2021). This practice is also highly problematic as it constitutes a potentially very high propagule pressure of introduced species (repeated introductions of many individuals in many places). Bees emerging from cocoons can also compete with native bees for floral resources. For example, Osmia cornifrons a species whose cocoons are sold online, is exotic in the United States and has been recently associated to the strong decline of six native mason bee species either due to resources competition, pathogen spillover or both (LeCroy et al.2020). As Osmia cornifrons, all bee species currently sold online are Megachillidae which is also the most represented bee family among the exotic and invasive bee species recorded worldwide (Russo 2016). Buying bees online could also arise the risk of transmitting diseases (Aizen et al. 2020). Parasites and diseases are widespread in animal husbandry, and even when all possible precautions are taken, the spillover hazard can never reach zero. For example, Hedtke et al.(2015), demonstrated that $O$. cornifrons transported fungi from its native range Japan to the United States. Hence, we believe that the trade of bee cocoons online is also a misplaced conservation practice as it a) misinforms the public and blur their perception of the importance of wild bees especially the native ones, b) leads to a misallocation of resources: instead of protecting the local populations, people invest funds in reared species, and c) potentially harms biodiversity by fostering the spread of exotic species, increasing competition for floral resources and favouring potential pathogens spillover.

\section{Conclusion :}

Misplaced conservation practices have multiplied in recent years (Fordet al. 2021), mainly through the rapid dissemination of simplified information, putting ecological knowledge and its complexity aside. The first step towards more appropriate measures is to inform companies, citizens, and decision-makers about the complexity of species interactions and orientate their choices based on scientifically sound arguments. Research in conservation ecology should continue to be developed to offer comprehensive tools to whom want to set up conservation practices. For bees, ensuring sufficient resources by promoting local and native flowering plants, preserving, and protecting nesting and reproductive sites, is better than introducing more individuals (especially without considering which species). Removing current threats on pollinators, such as the agrochemical use, appears more efficient and more logical than trying to boost existing, threatened populations. Finally, it is still possible to buy or build a bee hotel with substrates adapted to local populations while avoiding the establishment of non-native bee species. These have the added benefit to educate people involved about ecological concepts as well as to reconnect them with nature, two aspects that are likely pursued by those willing to help biodiversity in general, and bees in particular.

Acknowledgements : We sincerely thanks Sherry Stanbury for English editing. We also deeply thanks Franck Courchamp, Boris Leroy, Bertrand Schatz and Hervé Jourdan for their help on previous versions of this article.

\section{References}

Aizen, M.A., Arbetman, M.P., Chacoff, N.P., Chalcoff, V.R., Feinsinger, P., Garibaldi, L.A., et al. (2020). 
Invasive bees and their impact on agriculture. Adv. Ecol. Res. 1st edn. Elsevier Ltd.

Angelella, G.M., McCullough, C.T. \& O'Rourke, M.E. (2021). Honey bee hives decrease wild bee abundance, species richness, and fruit count on farms regardless of wildflower strips. Sci. Rep. , 11, 1-12.

Baldock, K.C. (2020). Opportunities and threats for pollinator conservation in global towns and cities. Curr. Opin. Insect Sci. , 38, 63-71.

Bang, A. \& Courchamp, F. (2021). Industrial rearing of edible insects could be a major source of new biological invasions. Ecol. Lett. , 24, 393-397.

Bradshaw, C.J.A., Leroy, B., Bellard, C., Roiz, D., Albert, C., Fournier, A., et al. (2016). Massive yet grossly underestimated global costs of invasive insects. Nat. Commun., 7, 12986.

Colla, S.R. \& MacIvor, J.S. (2017). Questioning public perception, conservation policy, and recovery actions for honeybees in North America. Conserv. Biol. , 31, 1202-1204.

Dainese, M., Riedinger, V., Holzschuh, A., Kleijn, D., Scheper, J. \& Steffan-Dewenter, I. (2018). Managing trap-nesting bees as crop pollinators: Spatiotemporal effects of floral resources and antagonists.J. Appl. Ecol. $, 55,195-204$.

Deguines, N., de Flores, M., Loïs, G., Julliard, R. \& Fontaine, C. (2018). Fostering close encounters of the entomological kind.Front. Ecol. Environ. , 16, 202-203.

Diagne, C., Leroy, B., Vaissière, A.C., Gozlan, R.E., Roiz, D., Jarić, I., et al. (2021). High and rising economic costs of biological invasions worldwide. Nature, 592, 571-576.

Drossart, M. \& Gérard, M. (2020). Beyond the decline of wild bees: Optimizing conservation measures and bringing together the actors.Insects , 11, 1-23.

Egerer, M. \& Kowarik, I. (2020). Confronting the Modern Gordian Knot of Urban Beekeeping. Trends Ecol. Evol. , 35, 956-959.

Le Féon, V., Aubert, M., Genoud, D., Andrieu-Ponel, V., Westrich, P. \& Geslin, B. (2018). Range expansion of the Asian native giant resin bee Megachile sculpturalis (Hymenoptera, Apoidea, Megachilidae) in France.Ecol. Evol. , 8, 1534-1542.

Ford, A.T., Ali, A.H., Colla, S.R., Cooke, S.J., Lamb, C.T., Pittman, J., et al. (2021). Understanding and avoiding misplaced efforts in conservation. FACETS , 6, 252-271.

Geldmann, J. \& González-Varo, J.P. (2018). Conserving honey bees does not help wildlife. Science (80-). , 359, 392-393.

Geslin, B., Gachet, S., Deschamps-Cottin, M., Flacher, F., Ignace, B., Knoploch, C., et al. (2020). Bee hotels host a high abundance of exotic bees in an urban context. Acta Oecologica , 105, 103556.

Geslin, B., Gauzens, B., Baude, M., Dajoz, I., Fontaine, C., Henry, M., et al. (2017). Massively Introduced Managed Species and Their Consequences for Plant-Pollinator Interactions. Adv. Ecol. Res., 57, 147-199.

Gippet, J.M.W. \& Bertelsmeier, C. (2021). Invasiveness is linked to greater commercial success in the global pet trade. Proc. Natl. Acad. Sci. U. S. A., 118.

Graystock, P., Yates, K., Evison, S.E.F., Darvill, B., Goulson, D. \& Hughes, W.O.H. (2013). The Trojan hives: pollinator pathogens, imported and distributed in bumblebee colonies. J. Appl. Ecol. , 50, 1207-1215.

Hedtke, S.M., Blitzer, E.J., Montgomery, G.A. \& Danforth, B.N. (2015). Introduction of non-native pollinators can lead to trans-continental movement of bee- Associated fungi. PLoS One , 10, 1-18.

Henry, M. \& Rodet, G. (2018). Controlling the impact of the managed honeybee on wild bees in protected areas. Sci. Rep. , 8, 1-10. 
Herbertsson, L., Lindström, S.A.M., Rundlöf, M., Bommarco, R. \& Smith, H.G. (2016). Competition between managed honeybees and wild bumblebees depends on landscape context. Basic Appl. Ecol. , 17, 609-616.

Herrera, C.M. (2020). Gradual replacement of wild bees by honeybees in flowers of the Mediterranean Basin over the last 50 years. Proc. R. Soc. B Biol. Sci. , 287, 16-20.

Hung, K.-L.J., Kingston, J.M., Lee, A., Holway, D.A. \& Kohn, J.R. (2019). Non-native honey bees disproportionately dominate the most abundant floral resources in a biodiversity hotspot. Proc. $R$. Soc. B Biol. Sci. , 286, 20182901.

Ivanov, S.P. \& Fateryga, A.V. (2019). First record of the invasive giant resin bee Megachile (Callomegachile) sculpturalis Smith, 1853 (Hymenoptera: Megachilidae) in the Crimea. Far East. Entomol. , 395, 7-13.

Koffler, S., Barbiéri, C., Ghilardi-Lopes, N.P., Leocadio, J.N., Albertini, B., Francoy, T.M., et al. (2021). A buzz for sustainability and conservation: The growing potential of citizen science studies on bees. Sustain. , $13,1-15$.

von Königslöw, V., Klein, A.M., Staab, M. \& Pufal, G. (2019). Benchmarking nesting aids for cavity-nesting bees and wasps.Biodivers. Conserv. , 28, 3831-3849.

LeCroy, K.A., Savoy-Burke, G., Carr, D.E., Delaney, D.A. \& Roulston, T.H. (2020). Decline of six native mason bee species following the arrival of an exotic congener. Sci. Rep. , 10, 1-9.

Lorenz, S. \& Stark, K. (2015). Saving the honeybees in Berlin? A case study of the urban beekeeping boom. Environ. Sociol. , 1, 116-126.

MacIvor, J.S. \& Packer, L. (2015). 'Bee Hotels' as Tools for Native Pollinator Conservation: A Premature Verdict? PLoS One, 10, e0122126.

Magrach, A., González-Varo, J.P., Boiffier, M., Vilà, M. \& Bartomeus, I. (2017). Honeybee spillover reshuffles pollinator diets and affects plant reproductive success. Nat. Ecol. Evol. , 1, 1299-1307.

Mallinger, R.E., Gaines-Day, H.R. \& Gratton, C. (2017). Do managed bees have negative effects on wild bees?: A systematic review of the literature. PLoS One, 12, e0189268.

Michener, C.D. (2007). The bees of the world . 2nd Ed. The Johns Hopkins University Press, Baltimore.

Rahimi, E., Barghjelveh, S. \& Dong, P. (2021). How effective are artificial nests in attracting bees? A review. J. Ecol. Environ., 45, 16.

Renner, S.S., Graf, M.S., Hentschel, Z., Krause, H. \& Fleischmann, A. (2021). High honeybee abundances reduce wild bee abundances on flowers in the city of Munich. Oecologia , 195, 825-831.

Ropars, L., Affre, L., Schurr, L., Flacher, F., Genoud, D., Mutillod, C., et al. (2020). Land cover composition, local plant community composition and honeybee colony density affect wild bee species assemblages in a Mediterranean biodiversity hot-spot. Acta Oecologica, 104, 103546.

Ropars, L., Affre, L., Thébault, E. \& Geslin, B. (2022). Seasonal dynamics of competition between honey bees and wild bees in a protected Mediterranean scrubland. OIKOS , e08915.

Ropars, L., Dajoz, I., Fontaine, C., Muratet, A. \& Geslin, B. (2019). Wild pollinator activity negatively related to honey bee colony densities in urban context. PLoS One , 14, e0222316.

Russo, L. (2016). Positive and Negative Impacts of Non-Native Bee Species around the World. Insects , 7 , 69.

Russo, L., de Keyzer, C.W., Harmon-Threatt, A.N., LeCroy, K.A. \& MacIvor, J.S. (2021). The managed-toinvasive species continuum in social and solitary bees and impacts on native bee conservation.Curr. Opin. Insect Sci. , 46, 43-49. 
Schatz, B., Maxime, D., Mickael, H., Benoît, G., Fabrice, A., Colette, S., et al. (2021). Pollinator conservation in the context of global changes with a focus on France and Belgium. Acta Oecologica, 112, 103765.

Smith, T.J. \& Saunders, M.E. (2016). Honey bees: the queens of mass media, despite minority rule among insect pollinators. Insect Conserv. Divers. , 9, 384-390.

Stange, E., Zulian, G., Rusch, G., Barton, D. \& Nowell, M. (2017). Ecosystem services mapping for municipal policy: ESTIMAP and zoning for urban beekeeping. One Ecosyst., 2, e14014.

Stevenson, P.C., Bidartondo, M.I., Blackhall-Miles, R., Cavagnaro, T.R., Cooper, A., Geslin, B., et al. (2020). The state of the world's urban ecosystems: What can we learn from trees, fungi, and bees? Plants, People, Planet , 2, 482-498.

Straffon-Diaz, S., Carisio, L., Manino, A., Biella, P. \& Porporato, M. (2021). Nesting, Sex Ratio and Natural Enemies of the Giant Resin Bee in Relation to Native Species in Europe. Insects, 12, 545.

Sumner, S., Law, G. \& Cini, A. (2018). Why we love bees and hate wasps.Ecol. Entomol. , 43, 836-845.

Thomson, D. (2004). Competitive Interactions Between the Invasive European. Ecology , 85, 458-470.

Torne-Noguera, A., Rodrigo, A., Osorio, S. \& Bosch, J. (2016). Collateral effects of beekeeping: Impacts on pollen-nectar resources and wild bee communities. Basic Appl. Ecol. , 17, 199-209.

Valido, A., Rodriguez-Rodriguez, M.C. \& Jordano, P. (2019). Honeybees disrupt the structure and functionality of plant-pollinator networks.Sci. Rep. , 9, 1-11.

Zattara, E.E. \& Aizen, M.A. (2021). Worldwide occurrence records suggest a global decline in bee species richness. One Earth , 4, 114-123.

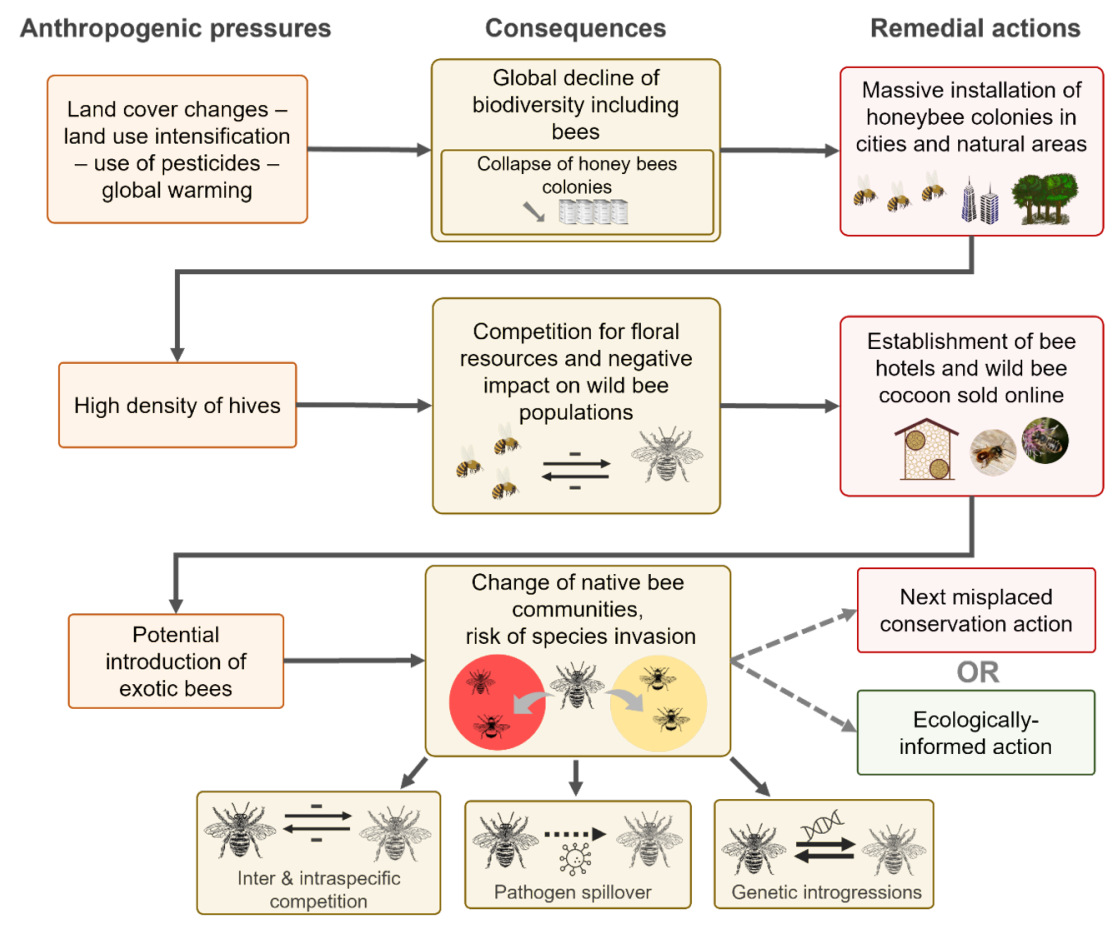

Figure 1: Conceptual framework of the misplaced management of bees. Boxes in orange indicate anthropogenic induced pressures. Boxes in yellow indicate the consequences of these pressures on bee populations. Boxes in red indicate the misplaced remedial management of bees. 